\title{
MOSSES OF PICEA CRASSIFOLIA FOREST IN HELANSHAN (NINGXIA, CHINA)
}

\section{МХИ ЕЛЬНИКА ИЗ PICEA CRASSIFOLIA В ГОРАХ ХЕЛАН (НИНЬЯ-УЙГУРСКИЙ АВТОНОМНЫЙ РАЙОН, КИТАЙ)}

\author{
X.-L. BAI ${ }^{1}$, D.-P. ZHAO ${ }^{1}$, B.C. TAN ${ }^{2}$, E.A. IGNATOVA ${ }^{3} \&$ M.S. IGNATOV ${ }^{4}$ \\ Х.-Л. БАЙ ${ }^{1}$, Д.-П. ЧЖАО ${ }^{1}$, Б.Ч. ТАН ${ }^{2}$, Е.А. ИГНАТОВА ${ }^{3}$, М.С. ИГНАТОВ ${ }^{4}$
}

Abstract

An unusual xerophytic composition of mosses in Qinghai spruce (Picea crassifolia) forest in Helanshan is discussed. Abietinella abietina, Hypnum vaucheri, Pseudostereodon procerrimus, Trachycystis ussuriensis and Timmia bavarica are dominants of the moss layer under dense canopy of spruce. This composition is somewhat similar to that in P. schrenkiana forest in Middle Asia.

Резюме

Обсуждается моховой покров леса из Picea crassifolia, необычно богатого ксерофитными видами. Под густым пологом доминируют Abietinella abietina, Hypnum vaucheri, Pseudostereodon procerrimus, Trachycystis ussuriensis и Timmia bavarica. Проводится параллель со среднеазиатскими лесами из P. schrenkiana.

KEYWORDS: spruce, forest, mosses, plant communities, China, xeric areas

\section{INTRODUCTION}

The Helan Mountain Range, about $180 \mathrm{~km}$ long with a maximum elevation of $3556 \mathrm{~m}$, extends north as a fingerlike extension of the Qinghai-Tibetan Plateau. These mountains are situated at the western bank of the Huang He (Yellow River) valley where the river flows north across the Yinchuan Plain and separates the semi-arid Ordos temperate steppes and desert regions of the Alashan Plateau.

The lower elevations (ca. 1300-1700 m) and steep xeric slopes have semi-arid shrubs and scattered Ulmus pumila and U. glaucescens vegetation. In the interval of ca. 1700-2200 m, Pinus tabulaeformis (two-needle pine) forest prevails, sometimes with sufficient occurrence of Juniperus rigida. Above $2200 \mathrm{~m}$ and to the timberline at ca. $3000 \mathrm{~m}$, the Picea crassifolia forest occurs, covering both $\mathrm{N}$ and $\mathrm{S}$-facing slopes on the eastern macroslope of the Helan Mountains (Fig. 1).

Climate of the whole area is given by Shi et al. (1989) and discussed also by Zhao et al. (2006). According to these data, the discussed Picea forest occurs in interval of annual temperatures 0 to $+3{ }^{\circ} \mathrm{C}$ and precipitation $300-400 \mathrm{~mm}$, although direct observation is not available.

In historical time the forest of Helan Mountain has been logged for timber, while at present, the Helan Shan Nature Reserve (area of $1,570 \mathrm{~km}^{2}$ ) provides strict protection of its flora and fauna.

Qinghai spruce (Picea crassifolia Kom.) is a species of conifers restricted to the mountains and deserts at the eastern margins of the Qinghai-Tibe$\tan$ Plateau. It is represented by three populations

1 - Dept. of Biology, Inner Mongolia University, Hohhot 010021, China; e-mails: bxliangmoss@yahoo.com.cn \& topalizdp@yahoo.com.cn

2 - Department of Biological Science, National University of Singapore, Science Drive 4, Singapore, 119260; e-mail: dbsbct@nus.edu.sg

3 - Biological Faculty, Moscow State University, Moscow 119991 Russia - Россия 119991 Москва, Московский государственный университ, Биологический факультет, каф. геоботаники; e-mail: arctoa@list.ru

4 - Main Botanical Garden, Russian Academy of Sciences, Botanicheskaya 4, Moscow 127276 Russia - Россия 127276 Москва, ГБС РАН; e-mail: misha_ignatov@list.ru 
(in Qinhai west of Alashan Desert, in Helan and small population occurs in Daqing Mountains further to the East, in the middle range of Huang $\mathrm{He}$ River. Genetic data demonstrated a considerable difference of Helan population of this spruce from its main population in Qinhai-Tibetan Plateau (Meng et al., 2007). In addition, Helan spruce forest is unique being represented by large continuous forest massives, while Qinhai population is represented now usually by a rather small groups of trees, scattered in mountain slopes (Miehe et al., 2008), although in the past it was more widespread there.

Bryophyte flora of Helan mountain was actively studied in the recent years, yielding in a floristic account by Zhao et al. (2006) and a comprehensive flora by Bai (2010). In addition to species description, these publications briefly discuss composition of different plant communities, but one of them, namely the Picea crassifolia forest, is so unusual, that we decided to describe and illustrate it here additionally, mainly regarding its moss composition.

\section{OBSERVATIONS}

This paper is based mostly on observation in the $\mathrm{N}$-facing slopes at Huangqikou area (ca. $\left.38^{\prime} 40^{\circ} \mathrm{N}-105^{\prime} 55^{\circ} \mathrm{E}\right)$. Climbing up to this forest from 'pine belt' (1800-2200 m elev.) where the absence or at least extreme rarity of bryophytes among scattered xeric grasses looks quite natural, one reached the spruce forest with contrastingly continuous or at least well developed moss layer and almost no vascular plants (only scattered Carex lanceolata occurs at places). This fact itself would not be surprising, as Picea is one of the best shade-provider tree. However, almost throughout northern Holarctic region, Picea forests are associated with such mosses as Pleurozium, Hylocomium, Rhytidiadelphus triquetrus. None of them were found in Helan.

Contrary to this, the most common and abundant is Abietinella abietina, a moss that grows in relatively open xeric places in most of its range throughout northern part of the Holarctic region, although rarely occurs in open forests (see below). Further, in Helan spruce forest Timmia bavarica,
Hypnum vaucheri, Pseudostereodon procerrimus, and Entodon concinnus are abundant and locally dominating.

Among common, but less abundant species can be listed also Distichium capillaceum, Ditrichum flexicaule, Brachytheciastrum trachypodium, Trachycystis ussuriensis, Thuidium assimile, Isopterygiopsis pulchella, Amblystegium serpens, Brachythecium dahuricum (species recently segregated from B. salebrosum s.1.), B. cirrosum, Campylium hispidulum s.1., Didymodon rigidulus s.1.

Among more rare species there are Tortella fragilis, Myurella julacea, M. sibirica, Voitia nivalis, Brachythecium buchananii, Drummondia sinensis, Fissidens bryoides, Hypnum fauriei, Mnium spinosum, M. lycopodioides, M. heterophyllum, Plagiomnium confertidens, Pohlia cruda, Pylaisia polyantha, Rhytidium rugosum, Sanionia uncinata, Distichium inclinatum, Encalypta rhaptocarpa.

This account does not include species that grow on rock outcrops (Grimmia, Leucodon, Hymenostylium, Crossidium, Pseudoleskeella, etc.), or at the edge of the forest (Syntrichia, Tortula, Pterygoneurum, Weissia, etc.).

\section{DISCUSSION}

Although Picea forests have an overviewed report worldwide (cf. Walter, 1968), their moss composition has probably not been compared in detail in a sufficiently broad scope. The moss communities of most Picea forests are comprised of Pleurozium and Hylocomium types. More wet and oligotrophic habitats include Sphagnum (especially $S$. girgensohnii). The communities on rich soil (along brooks, etc.) in boreal zone and also hemiboreal spruce forests (especially Oxalis-type) are often characterized by abundant Brachytheciaceae, Plagiomnium and Rhytidiadelphus (in addition to ferns and herbs).

Pleurozium and Hylocomium forest types are the characteristic not only of Picea, but also of many northern types of Pinus and Larix forests, although in more xeric regions the latter ones include also Rhytidium, Aulacomnium, Tomentypnum, and Abietinella + Entodon types.

Figs. 1-7. Spruce forest in Helanshan. 1 - space photo of Helanshan (from http://www.worldwildlife.org/ wildworld/profiles/photos/pa/pa0508a.html); 2 - South-facing slopes; 3 - North-facing slope; 4-7 - views of spruce forest, showing moss layer of Timmia bavarica (4), Abietinella abietina (5), Hypnum vaucheri (6) and Pseudostereodon procerrimus (7). 

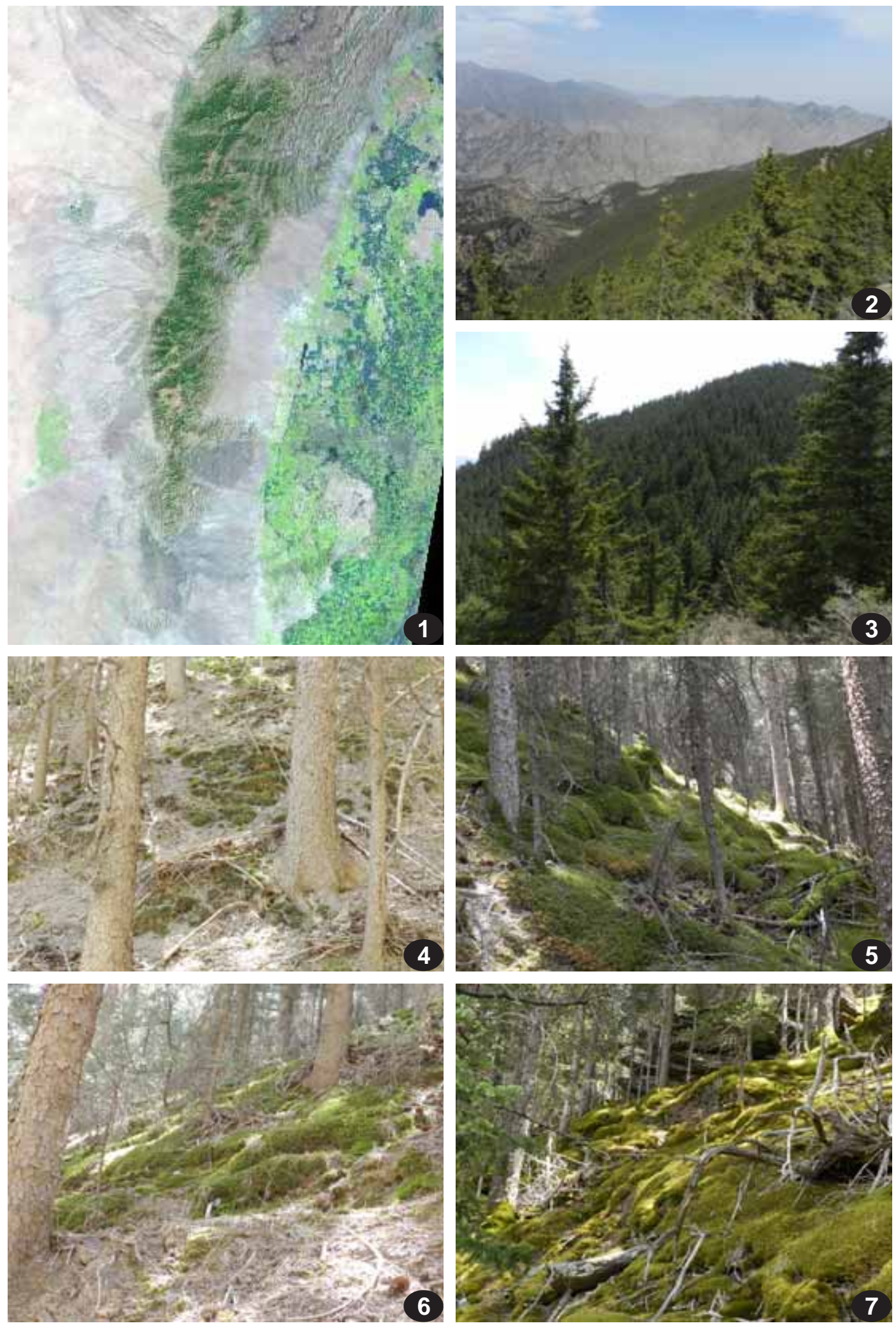

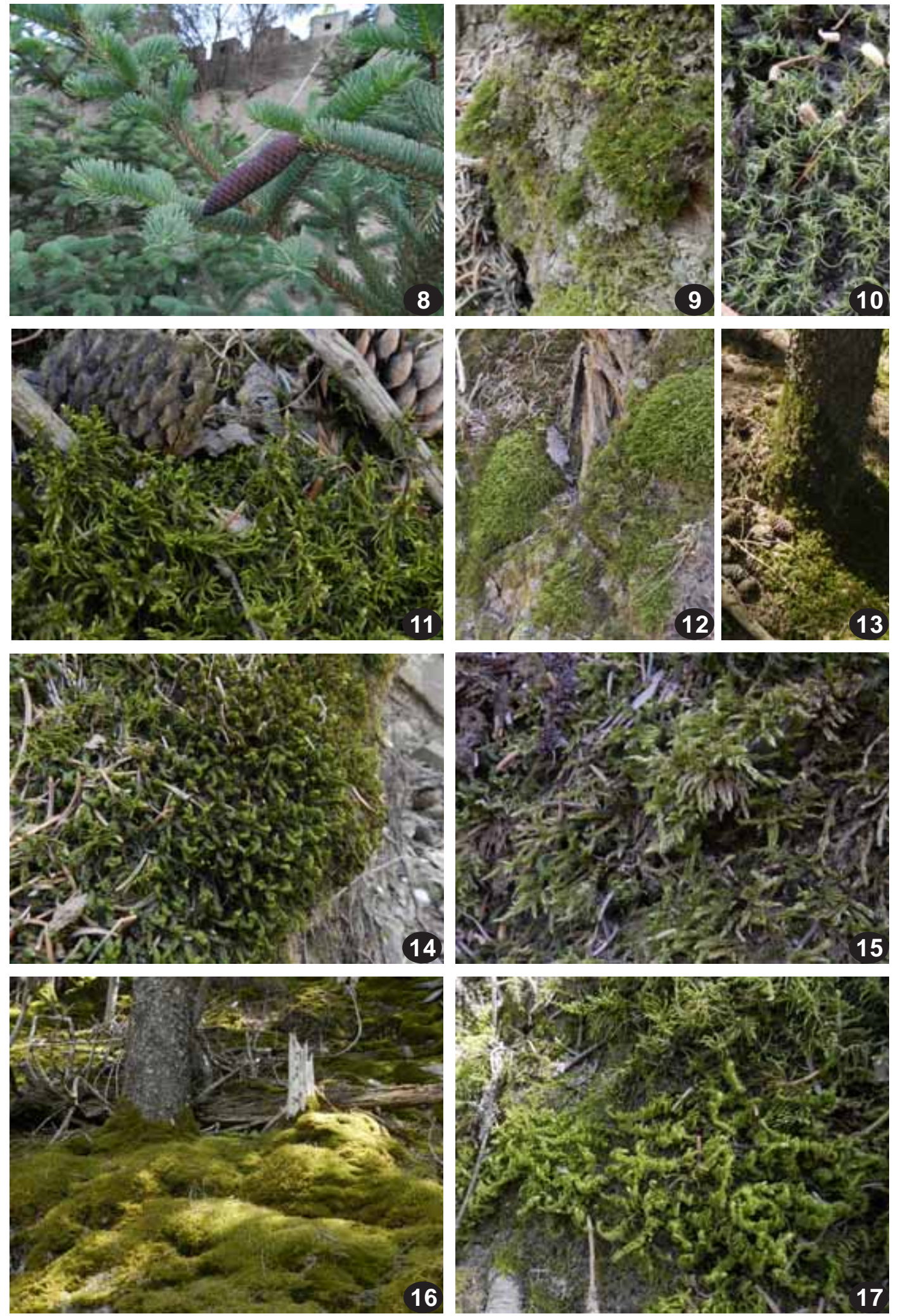
Abietinella and Entodon often grow together in grassland in Caucasus, Mongolia, and South Siberia. The typical habitats for them are open and shrubby slopes, while in Mongolia and south Siberia they commonly occur in Larix forests, and in Mongolia also participate in Larix +Picea forests, and even pure Picea obovata+Pinus sibirica forests (Tsegmed, 2002). However, the moss community in last mentioned forest type is still dominated by Hylocomium, Rhytidium, Pleurozium, with participation of Ptilium and Dicranum spp. In pure Picea forests Abietinella grows usually only as an admixture. The mountain spruce forests of South Siberia are usually more wet, leaving no room for Entodon and Abietinella that however are common in Larix forests in this area. Hylocomium and Pleurozium are the most common there, and two latter species are usually dominating in Larix forests too, including the most xeric area of Transbaikalia.

Likewise, according to our observations, $\mathrm{Pi}$ cea obovata forests in northern Xinjiang include Pleurozium and Hylocomium.

The same moss composition occurs in Picea forests of the Russian Far East where the Hylocomium and Pleurozium carpet is commonly enriched by Dicranum majus, Plagiothecium euryphyllum, Pleuroziopsis ruthenica and Pogonatum japonicum, and very rarely Actinothuidium.

In China, Picea forests in the North-East are similar to those in Russian Far East, while forests in Southwest China are very different, having a high diversity of vascular plants. At the same time, moss composition of the latter remains essentially the same, with the important addition of Actinothuidium. Dylis (1962) provided a nice description of spruce forests in the eastern part of Tibet Plateau at $27-34^{\circ} \mathrm{N}$ lat. (in Sichuan): conifer forests are comprised by numerous types, including the mossy one, where mosses cover 80$90 \%$ of the soil surface. Among the latter the dominant species are Actinothuidium, Hylocomium, Dicranum scoparium, Pleurozium schreberi, Rhytidiadelphus triquetrus, Pogonatum spp. Bao et al. (2009) studied the secondary spruce forests in Sichuan and listed the same moss carpet composition: Hylocomium, Actinothuidium, Thuidium, and also Entodon concinnus, Dicranum, Pla- giomnium, but with only very rare occurrence of Abietinella.

The most similar with Helan spruce forest in the moss species composition is the forest of $P i$ cea schrenkiana, a species closely related to $P$. crassifolia. It grows in Tian-Shan Mountains, mainly in Kazakhsan and in Xinjiang in China. Korovin (1962) provided an overview of these forests in Kazakhstan, indicating that the well developed soil substrates have moss carpet of $\mathrm{Hy}$ locomium splendens and Abietinella abietina, and closer to timber-line of Rhytidiadelphus triquetrus. At the same time the moss composition on poor undeveloped soils includes Tortella fragilis, Hypnum revolutum, and Schistidium gracile.

Bykov (1950) provided a more detailed classification of these Picea forests, reviewing data from neighboring mountains of Kazakhstan, Tarbagatai and Dzhungar Alatau, and also some ranges in Kyrgyzstan. He described a number of concrete sites of different variants of forests with more or less closed tree canopy, which we list here in full, omitting details of herbaceous layer and shrubs. The percentage value refers to the total moss coverage:

$70 \%$, prevailingly Brachythecium rutabulum;

$100 \%$, Rhytidiadelphus triquetrus (dominant), Sanionia uncinata, Dicranum scoparium, Brachythecium sp., Mnium spinosum, Leptobryum pyriforme, Distichium capillaceum, Polytrichum juniperinum, etc.);

95\%, Rhytidiadelphus triquetrus, Hylocomium splendens, Mnium medium, Hypnum revolutum, Dicranum scoparium;

90\%, Rhytidiadelphus triquetrus, Entodon concinnus, Abietinella abietina, Thuidium recognitum;

$75 \%$, Rhytidiadelphus triquetrus, Hypnum revolutum;

??\%, Abietinella abietina, Hypnum revolutum;

100\%, Abietinella abietina, Homalothecium philippeanum, Timmia bavarica, Encalypta ciliata, Syntrichia ruralis;

100\%, Abietinella abietina, Dicranum scoparium, Syntrichia papillosissima;

100\%, Abietinella abietina (Zailisky Alatau);

100\%, Hypnum revolutum, Rhytidiadelphus triquetrus, Mnium spinosum, Ditrichum flexicaule, Polytrichastrum alpinum;

95\%, Hylocomium splendens;

$? ? \%$, Entodon concinnus, Sanionia uncinata, Syntrichia ruralis, Polytrichum juniperinum, Dicranum scoparium.

Figs. 8-17. Spruce forest in Helanshan: 8 - Picea crassifolia; 9-10 - Timmia bavarica; 11 - Abietinella abietina; 12-13 \& 15 - Hypnum vaucheri; 14 - Trachycystis ussuriensis; 16-17-Pseudostereodon procerrimus. 
Quite abundant moss layer was recorded in many communities with well-developed herbaceous layer. The most common there are Rhytidiadelphus triquetrus and Hylocomium splendens, while among others are mentioned Sanionia uncunata, Dicranum scoparium, Brachythecium sp., Mnium spinosum, Plagiomnium medium, Entodon concinnus, Abietinella abietina, Thuidium recognitum, Plagiothecium sp., etc.

This long list from Bykov (1950) publication shows that the Tian-Shan spruce forests have sufficient similarity with Helan spruce forest, although the latter likely provides the extreme variant characterized by following:

1) Total absence of Pleurozium, Hylocomium, Rhitidiadelphus, only singe occurrence of Ptilium and Rhytidium (the latter is outside of forest above timber-line)

2) The flora has no species Dicranaceae and Polytrichaceae, which are common in boreal forests. The former family is totally absent in Helan, while the only one species of Polytrichaceae, Polytrichastrum alpinum, has been found in alpine meadow.

3) Hypnum vaucheri is common on forest floor. Usually this species grows in open xeric places.

4) The presence of Pseudostereodon procerrimus. This is a rare species that grows in open xeric places in Mongolia, SE Altai, East Caucasus, Taimyr. We never saw it so abundant as in Helan and never saw it under forest canopy.

5) The locally dominant xeric species are associated with species that are, in other parts of the world, more mesophytic or even mesohygrophytic, such as, Brachythecium cirrosum, Timmia bavarica, Isopterygiopsis pulchella, Campylidium hispidulum s.1., Myurella julacea, M. sibirica, etc.

Published data on "Thuidium-type" of Picea crassifolia forest [likely referring to Abietinella abietina $=$ Thuidium abietinum $]$ in Qinhai indicate probably the somewhat similar situation (Hao et al., 2005), although detailed bryological studies were not done here yet.

It seems that along its long history, the formation of xeric vegetation in Central Asia had lost the 'standard' moss elements of Picea forests, like Hylocomium and Pleurozium, and their niches were substituted by 'locally available' candidates, especially Hypnum vaucheri and Pseudostereodon procerrimus, that had developed their ability to tolerate shady habitats. The areas covered today by the xeric Picea forests were somewhat wet in the geologic past; this is indicated by the survival of the mesophytic and mesohygrophytic moss species that are primarily temperate in range.

\section{ACKNOWLEDGEMENTS}

The work was partly supported by RFBR 1004-91150, Russian Ministry of Science and Education 14.740.11.0165 and National Science Foundation of China (30900080, 30870160).

\section{LITERATURE CITED}

BAI, X-L. 2010. Bryoflora Helanshanica. - Typis Ningxia Popularis. Yinchuan. $281 \mathrm{pp}$. [In Chinese].

BAO, W, B. LEI, X. PANG, X. YAN \& Y. JIA 2009. Species composition and synusia structure of ground bryophyte communities under different aged spruce plantations and primary forest in the upper reaches of the Dadu River, Sichuan. Biodiversity Science 17(2): 201-209 [In Chinese].

[BYKOV, В.А.] БЫКОВ Б.А. 1950. Ельники Тянь-Шаня, их история, структура и типология. - [Picea forests of Tian-Shan, their history, structure and typology] Алма-Ama [Alma-Ata], $128 \mathrm{pp}$.

[DYLIS, N.V.] ДЫЛИС Н.В. 1962. Фитоценология темнохвойных лесов восточной части Тибетского Плато. - [Phytocoenology of dark coniferous forests of eastern part of Tibet Plateau] Проблемы ботаники [Problemy Botaniki] 6: 242-257.

HAO, H., X.-M. LIU, C.-F. SONG, J.-Q. LIU, D.-J. SHENG, J.-T. PENG \& Y.-S. ZHANG 2005. Spatial distribution pattern of predominant species in moss Picea crassifolia forest in north slope of Qilian Mountains. - J. Gansu Forestry Sciense and Technology 30(4): 9-12 [In Chinese].

[KOROVIN, E.P.] КОРОВИН Е.П.1962. Растительность Средней Азии и Южного Казахстана. Т. 2. - [Vegetation of Middle Asia and South Kazakhstan. Vol. 2.] Ташкент [Tashkent], $548 \mathrm{pp}$.

MENG, L., R. YANG, R.J. ABBOTT, G. MIEHE, T. HU \& J. LIU 2007. Mitochondrial and chloroplast phylogeography of Picea crassifolia Kom. (Pinaceae) in the Qinghai-Tibetan Plateau and adjacent highlands. - Mol. Ecol.: 16: 4128-4137.

MIEHE, G., K. KAISER, S. CO, Z. XINQUAN \& L. JIANQUAN 2008. Geo-ecological transect studies in Northeastern Tibet (Qinghai, China) reveal human-made mid Holocene environmental changes in the Upper Yellow River catchment changing forest to grassland. - Erdkunde 62(3): 187-199.

SHI, Y.Z., Y. H. SHI, Z.F. BAI \& J.Z. SUN 1989. Geography of Inner Mongolia. - In: Huhhot, Typis Intramongolicae Populations: 32-33 (in Chinese).

TSEGMED, TS. 2002. The list of mosses of Bogdkhan National Park (Mongolia). - Arctoa 15: 219-228.

WALTER, H. 1968. Die Vegetation der Erde. Bd 2. Jena, VEB Gustav Fisher Verlag.

ZHAO, D.-P., X.-L. BAI, X.-D. WANG \& H.-M. JING 2006. Bryophyte Flora of Helan Mountain in China. - Arctoa 15: 219-235. 